A Journal of Culture, English Language, Teaching \& Literature ISSN 1414-3320 (Print), ISSN 2502-4914 (Online)

Vol. 20 No. 2; December 2020

Copyright $@$ Soegijapranata Catholic University, Indonesia

American Dark Romanticism Characteristics in Lenore

\author{
${ }^{1}$ Khoe, Yohana Harsono and ${ }^{2}$ Ekawati Marhaenny Dukut \\ ${ }^{1,2}$ English Department, Faculty of Language and Arts \\ Soegijapranata Catholic University, Semarang, Indonesia \\ email: khoeyohana@gmail.com; ${ }^{2}$ ekawati@unika.ac.id
}

Received: 22-11-2019 Accepted: 11-06-2020 Published: 10-12-2020 


\title{
American Dark Romanticism Characteristics in Lenore
}

\author{
${ }^{1}$ Khoe, Yohana Harsono and ${ }^{2}$ Ekawati Marhaenny Dukut \\ 11khoeyohana@gmail.com; 2ekawati@unika.ac.id \\ 1,2English Department, Faculty of Language and Arts \\ Soegijapranata Catholic University, Semarang, Indonesia
}

\begin{abstract}
Analyzing the words and phrases used in Edgar Allan Poe's Lenore can portray the characteristics of the Dark Romanticism era of the United States of America, which consist of 1) imagination, 2) nature, 3) symbolism and myth, 4) intuition and subjectivity, and 5) individualism. Through a biographical and sociological approach, it was found that there were words in Lenore that support the Dark Romanticism characteristics. The dark, creepy, gloomy, and dreary, words that hint the feeling of Poe's uneasiness while living a dark and difficult life in the 1800 s in America were "no tear... weep now", "grief and groan", "Stygian River", "golden brown", "Hope", "Peccavimus", "Lenore" and "death".
\end{abstract}

Key words: Edgar Allan Poe, poem, romanticism era, dark romanticism, Lenore

\begin{abstract}
Abstrak: Menganalisis kata-kata yang digunakan oleh Edgar Allan Poe dalam puisinya Lenore dapat memperlihatkan karakteristik dari masa Dark Romanticism yang dialami oleh negara Amerika Serikat, yaitu adanya karakteristik: 1) imagination, 2) nature, 3) symbolism and myth, 4) intuition and subjectivity, dan 5) individualism. Melalui pendekatan biografi dan sosiologi maka ditemukan beberapa kosa kata dari puisi Lenore yang mendukung masa Dark Romanticism yang dipenuhi dengan lingkungan yang gelap, menyeramkan, dan menyedihkan itu. Beberapa kosa kata yang menandakan ketidaknyamanan Poe dalam melalui kehidupannya pada tahun 1800an di Amerika Serikat adalah kata "no tear... weep now", "grief and groan”, "Stygian River”, "golden brown”, "Hope”, "Peccavimus", "Lenore" and "death".
\end{abstract}

Kata kunci: Edgar Allan Poe, puisi, era romantisisme, dark romanticism, Lenore 


\section{INTRODUCTION}

American Romanticism was influenced by the Romanticicism Movement that happened in England in the eighteenth century and continued onwards to the early nineteenth century (Habich \& Nowatzki, 2010, pp. 4-5). According to Wellek (1962, pp. 1-4), this era is characterized by a movement when the theme in the literary world experiences a change from classical and neoclassical conventions to the romantic theme. In the Neoclassical movement "rationality and logic were emphasized and imagination was discouraged" (Matthews, 2014, p. 2).

The Romantic Movement included writers such as William Wordsworth, Samuel Taylor Coleridge and Edgar Allan Poe. The Romantic Era was an era where poets tend to want nature and imagination of the calm and orderly country side to rule over the disordered city life. Romantic poets believed that nature was God's manifestation that the imagination can be risen to the fullest. In the Romanticism era, there are five basic characteristics that makes Romantic poetry stand out. The characteristics are the evidences for imagination, nature, symbolism and myth, intuition and subjectivity, and individualism (Stobaugh, 2012, p. 315). In the literary world, the works of the Romanticism period are divided into two: the Light and Dark Romanticism (Dinçer, 2010). The Light romanticism contains every good thing that people want to achieve in life. The light side is very different from the Dark Romanticism that contains all of the bad things in human's life. The works categorized in Dark Romanticism mostly have poetry that has an unhappy ending, because the poetry often contain dark, creepy, gloomy, and dreary tones. One of the authors who uses Dark Romanticism characteristics in his poems is the American, Edgar Allan Poe.

Edgar Allan Poe is one of the major literature authors in American Romanticism. Poe is well known for his work that presents a romantic theme in a dark way. Poe's works are often inspired by his own life that is filled with the feelings of sorrow, despair, anger, and suffer from losing his loved ones. His experience of losing people that he loved has opened the gate for Poe to be the father of works with the theme of death. Most of his literary work end with the death of his fictional characters. The death that always appear in Poe's work is usually the death of a female character. This can be seen from Poe's works, such as Eleonora, Ligeia, Berenice, Morella, and Lenore. Poe loves to write the death of a woman character as his favorite star. It seems that he wants to share his own feelings when he sees two beloved women in his life, his mother and his wife, die in front of his own eyes. Poe admitted that he 
believes that the most poetical topic in the world is about the death of a young woman (Poe, 1846). This article will discuss about his poem that gives a clear example of the death of young woman, ie. Lenore.

Lenore is a popular poem written by Poe in 1843 . The title takes exactly the same name as one of his lovers, a young woman named Lenore. In this poem, Guy de Vere is the man whose lover passes away because of illness. Unlike the man in The Raven who could not accept the reality of his lover's death, the man in this poem accepts the fact that his Lenore does not exist anymore. Guy de Vere talks to the narrator that he believes that his Lenore is happier in heaven and is waiting for him. The girl's name Lenore in this poem is very interesting to be analyzed. It is because this name invites the readers of this poem to find out about the real identity of Lenore and the reason why Poe chooses her as the woman character in Lenore. Many people try to identify the figure of Lenore in Poe's poems. There is a thinking that Lenore is the name of a woman who gives a big impact to Poe's life besides Poe's wife, Virginia. Hammond (1981) is in support of this thinking, when he informed in An Edgar Allan Poe Companion: A Guide to the Short Stories, Romances and Essays, the fact that Lenore refers to Poe's wife, Virginia Clemm.

A continually recurring theme in the poetry, as in the short stories, is the quest for eternal perfection as personified by a feminine character of rare beauty. Just as Ligeia, Eleonora, and Berenice symbolized for Poe the elusive beauty he had found and lost in the person of Virginia Clemm, so Annabel Lee, Helen, Eulalie, and Lenore personified for him his idée fixe of departed love, of happiness transitorily experienced but never to be tasted again... (1981, p. 155).

There is proof that Lenore is also a symbol of Poe's "darling little wife" in Life of Edgar A. Poe (1879). Didier says that "Poe and his Lenore's" picture is on his desk and there is a sweet interaction between Poe and Virginia (1879, pp. 94 101). Didier also states that Poe has written his and his wife's love story in one of Poe's works, Eleonora (1879, p. 58). The meaning of the title on "What Shall We Name the Baby?" for Eleonora according to Wilson (2015, p. 104$105)$ has the same meaning as Lenore. This is supported by Griffin (2014, p. 117) who points out that these names come from different language yet have the same meaning, that is, light.

The names Eleanora and Lenore are commonly given to a baby girl. These names refer to a wealthy and elegant woman. It can be interpreted that 
Virginia gives a big impact to Poe's life until it affects Poe's works. Didier (1879) writes that Poe is hitting the lowest point of his life after Virginia's death. After her death, Poe has changed himself into somebody else. He does not seem to care about his life anymore. There is no doubt to say that Poe thinks that his wife is his light and life. Didier says that Poe writes The Raven and Lenore during the sickness of Virginia and Poe starts anticipating the possibility of Virginia's death in his poems $(1879$, p. 100). This is the reason why Poe chooses Lenore as the name of his woman's character in Lenore. Lenore does not only show people about Poe's love towards Virginia and his condition after Virginia's death but this poem also represents the characteristics of romanticism era that consist of dark romanticism side in its words and phrases. Lenore is the works related to this period that does not only represent the characteristics of Romanticism period but the words it uses in the poem also tells the condition of Romanticism Era environment.

\section{LITERATURE REVIEW}

\section{A. Biography of Edgar Allan Poe}

Edgar Allan Poe came from Boston, Massachusetts. Elizabeth Arnold Poe had given birth to him on January 19, 1809. Unfortunately, Poe's parents had passed away when he was in an early age. As a result, Poe had to be adopted by Allan's family. Poe's foster parents, John and Frances Allan, had to take care of Poe but in the fact only Frances Allan who insisted to take care after him. According to Hammond (1981), Poe became the heir of John Allan, Poe's step-father, who was a successful exporter. In the new family, Poe experienced the love of a mother from his step mother, Frances Keeling Valentine Allan.

Young Poe got a good education because his step father really cared about his education. He entered the finest school in Richmond and continued his education to University of Virginia at Charlottesville. It seemed that Poe's life was going to be bright because he was going to get Allan's inheritance. Unfortunately, Poe had to face sadness and emptiness when Frances died. The death of France did not only give a big impact to Poe's psychology but also Poe's life and future. Allan got married again and had his own children. His new wife wanted Allan's inheritance, that would become Poe's property, became her children's. Poe decided to leave Allan's family and moved to Boston after having quarrel with his father. In Boston, Poe tried to 
start his literary career. His first work was Tamerlane and Other Poems. Poe got married to his cousin, a thirteen-years-old-cousin, Virginia Eliza Clemm. The marriage between cousins was not really common at the time. Maria Poe, Virginia's mother, did not have good trust to Poe about the caring of Virginia. It happened because Maria thought about two conditions, Poe's financial condition and Virginia's very young age. Thus, Poe had to work very hard to make Maria believe in him.

The marriage life of Poe and Virginia was a happy life for Poe. The feeling of loneliness that Poe always had because of the death of his mother vanished as it was erased by Virginia. Virginia was the only one who followed wherever Poe went, and whatever Poe needed. She was also the love messenger between Poe and a neighbor. She adored Poe and accepted Poe with all of her heart. It made Poe feel that he was not alone anymore and Poe started to have a deep love toward his little wife. Unfortunately, Virginia passed away when she was really young due to her illness, tuberculosis. Once again, Poe had to face the sorrow feeling caused by the death of his beloved person.

During his life, Poe had to experience the death of several women that he loved: his mother, his foster mother, and his young wife. According to Didier, the death of Elizabeth Arnold Poe and Frances Keeling Valentine Allan was still mysterious. There was no further information about their death. In Life of Edgar Allan Poe, Didier (1879) just said that both of them died because of natural causes. Fortunately, Case $\&$ Semtner (2009) gave a fact to people about the causes of their death. Interestingly, the reason of their death was tuberculosis just as the reason of Virginia's death. The death of his loved women brings Poe into sadness and loneliness that lead him into his own illness.

\section{B. Background of American Romanticism Era}

The romanticism era was the movement when literary works' theme changed from classical and neoclassical conventions, when people were against the using of individualism and imagination and shifting to the romantic theme that gave the priority to individualism and imagination (Wellek, 1962). The romanticism era happened because the war at the time had caused a great depression that led people to want to nurture hope and optimism of the $18^{\text {th }}$ century. The first place that has this movement was Germany but this movement rapidly spread to England, France, and America. 
In the United States of America, this movement happened during the period of national expansion and reform. It was the time when Americans realized the identity and voice of American. Though Americans recognized it and wanted to have a better life, the condition of environment did not support it. Taylor (2009, pp. 307-326) says in Environmental Sociology from Analysis to Action that people from laboring class and people from middle to lower class had to live in a very bad environment. Taylor (2009, p. 309) states that their houses were located in crowded, insecure, and unhealthy environment. Their houses were also too expensive for them because they just got a very little wages despite the fact that they had been working for long hours in abominable working place. During this time, people from middle to lower class did not find a safe and clean open space like a ball field or park. It was because they just find under developed places and parks where there were full of homeless and unemployed people. During the 1800s, people experienced the condition of having lack of sanitation, clean water, and public open space. It made many people die because they suffered from poverty and poor health. There was no medical support, either from doctors or from medicines, available at the hospital to cure the unhealthy people so people could only wait the death. There were many diseases that killed people.

One of the diseases was tuberculosis. According to Frith \& Villemin (2014), tuberculosis became an epidemic and caused million deaths during the $18^{\text {th }}$ century to $19^{\text {th }}$ century. People who had this disease were people who came from the low class in society. Tuberculosis was also called "the robber of youth" (Frith \& Villemin, p. 32) and was connected to the conditions of society at the time when people experienced the condition of being extremely poor and lack nutrition. This condition gave effect to the literary world in America. This is why the death theme in American literature could not be separated from the Romanticism Era because at the time people experienced death by seeing people who suffer and die every day. This experience of death and love from people whom was left by the death one gave a true feeling that made the American literature works look modern and gave the sense of pureness.

\section{Literary Writing in Romanticism Period}

Dinçer (2010) states that Romanticism Era has two sides of literary writing, ie. "light romanticism" and "dark romanticism". In Light Romanticism, the author provides all of the good things that people can get in their life. The works in Light Romanticism tells people that there are no bad people in the world and there is no failure that they can encounter. This side 
emphasizes the fact that people cannot prevent everything which is changed in their lives but they have the opportunity to forget the past. It is very different from Dark Romanticism.

In Dark Romanticism, the works will tell the bad side of individual. The individuals have to commit their fault and their destruction. In this side, ones are not successful to change their lives to become better. It is because the Dark Romanticism contains all of bad things of ones' lives. The works of the Dark Romanticism always contain dark, creepy, gloomy and dreary tones mostly with unhappy ending. The Dark Romanticism is the side that Poe has chosen to writing his works. It makes Poe's works have to tell about dark, creepy, gloomy and dreary tones.

According to Stobaugh (2012, p. 315), there are five characteristics of literary work in the Romanticism Era, those are, imagination, nature, symbolism and myth, intuition and subjectivity, and individualism. The Romanticism characteristics are supported by Fiedler (2003) who states that literature works that have romantic theme usually aim to sastisfy people's emotional needs. That is why people in the romanticism era would prefer to think more about their emotion and feeling rather than their logic. They used to think more about love and praised nature. It made people have no reason to think that they would hate people or they would encounter failure in their life. They imagined and thought that they were better than others.

The works in Romanticism writing often give sentimental and unrealistic feelings to the reader. It is because the romantic works contain the strong emotional relation between the writers and the readers. The authors of the stories have to bring the feeling of fear, love, optimism, and anxiety as the main factors in their works. The value of the romantic writings that the writers write depends on how great they exaggerate and explain their works.

\section{METHOD}

In this study, we use a qualitative method to collect the data. According to Hennink, Hutter, \& Bailey (2011, p. 8-9), it is difficult to define about the qualitative method because qualitative methods contain a wide range of techniques and philosophies, but the qualitative method is a method that consists of a deep investigation. Researchers using the qualitative method are allowed to examine the experience that people have in their lives. This 
method gives to the researchers the descriptions of complex textual about how ones have experience about particular issue.

Shortly, it gives information about the human's side of an issue. The information about human issues includes people's behaviors, beliefs, opinions, emotions, and relationships. Other factors like social norms, socioeconomic status, gender roles, ethnicity, and religion are also analyzed with qualitative research. This is why, in this article, the qualitative method is applied by studying and describing what is found through analyzing Edgar Allan Poe's Lenore.

\section{FINDINGS AND DISCUSSIONS}

In this section, we analyzed the words and phrases that give information about the Romanticism Era characteristics, which also represent the characteristics of Dark Romanticism Era in the poem Lenore, which was made by Poe in 1843 (Parker, 2005, Lenore, pp. 193-194).

\section{A. "Golden Bowl"}

The beginning of the poem is opened by the unknown who talks to De Vere. He opens the poem by stating:
Ah, broken is the golden bowl! the spirit flown forever!
Let the bell toll! -a saintly soul floats on the Stygian river - And, Guy De Vere, hast thou no tear? -weep now or never more!
See! on yon drear and rigid bier low lies thy love, Lenore!
Come! let the burial rite be read -the funeral song be sung! - An anthem for the queenliest dead that ever died so young - A dirge for her, the doubly dead in that she died so young. (Parker, 2005, Lenore, p. 193, stanza 1, line 1)

In our opinion, the using of the word "golden" is representing something which gives the promise that this thing will be very precious. The bowl itself is the container to accommodate that precious thing. If the bowl is broken like the bowl in this poem, it means that the thing, which is very expensive and full of successful promises, and cannot be used anymore. If the bowl is broken, then it is going to the trash, because there is no value anymore from this bowl. It makes us assume that this bowl represents Lenore's life that has to be ended by her sickness and the promise of happiness that must be 
ended because of Lenore's death. Lenore could be married with Guy De Vere and could have a good family until she is old. Unfortunately, the promise of happiness cannot be fulfilled because she dies when she is so young. This broken future can be related to Poe and Virginia's life as discussed below.

Based on what Didier (1879) said about Poe and Virginia's marriage life, it seemed that they had a happy marriage. They were completely in love toward each other. They most likely dreamt about growing old together and have many children and grandchildren. It was possible because they were at a young age at the time, so they could try to make their dreams come true. The dream about having a better life means also living in a better environment. This is pronounced as a dream, because the condition of environment at the time did not support a good life for a family, so it becomes obvious that both of them had an imagination about a good environment where their children could live in. Sadly, all of their dreams were vanished when tuberculosis killed Virginia. So, their dreams were broken and it could not be repaired anymore. It brings Poe to express his sadness feeling due to the loss of Virginia and their dreams within the phrase "golden bowl" that can represent the dark, dreary tone and unhappy ending of the dark romanticism era.

\section{B. "Stygian River"}

"Stygian River" in this poem is located in the beginning of the poem when the narrator opens the conversation with Guy De Vere. The unknown narrator forces De Vere to be sad and therefore, exclaimed "Let the bell toll! -a saintly soul floats on the Stygian River" (Parker, 2005, Lenore, p. 193, stanza 1, line 2). This phrase is categorized as the phrase that represents the myth and symbolism aspect. People around Poe's environment at that time was believing in a myth that the Stygian River became a gate way from Earth to the Underworld.

In this case, we believe that the narrator uses this river to say that the pure Lenore is crossing the Stygian River to go to heaven. This means that once Lenore goes in the river there is no turning back for Lenore to go to earth anymore. The river also symbolizes hatred. It is not because the myth of this river that presents about the myth of Hatred and the Underworld, but it is because the feeling of hatred belongs to "a saintly soul", which has passed away. This saintly soul, whom the narrator talks about is Lenore. The fact that the pure Lenore dies at a very young age makes De Vere upset. De Vere is not only sad but he is also angry about the fact that he could not be together with Lenore anymore. He hates this fact and the narrator knows about it. This 
abhorrence is also felt by Poe when in reality he could only sit and watched Virginia die because of tuberculosis. There was ill feeling inside Poe who hated the fact that tuberculosis was killing all of his loved ones and there was nothing that he could do to stop it. This is the reason why Stygian River can appear as a symbol for a dreary tone, which is dark, and gives an unhappy ending.

From "Stygian River", there is also an imagination aspect about the imagination of environment condition that Poe wants to illustrate through his poem at the time. Stygian river in his poem seems to also refer to the Greek myth that becomes the gate for the dead to go to the Underworld. In the Greek myth, the river is not a dirty river where no trash can be found and no stingy smell can be detected. This river is very clean until the keeper of this river can easily take the dead to the Underworld by crossing the river with a smooth sailing boat.

This river is very different from the real Stingy River that Poe saw when he made this poem. The river that Poe saw in his life was a dirty river because people would often throw trash or garbage into this river. This made the plants in the river grew wild and became dirtier because wasted things were stuck in the plants. It was very difficult for people to cross the river because a boat could be stuck in the plants or garbage, that people could not cross or enjoy the river.

Poe seems to want some good opportunity of having the river, when he wrote in second line of the first stanza that says "Let the bell toll! -a saintly soul floats on the Stygian River -". The word "floats" can be the signal that Poe wanted to float in the river by riding a boat. Poe probably had a fantasy to spend some of his time with Virginia in a boat or walked the river walk with her. Regrettably, he could not do it because of the bad condition of the river. It was the reason why he decided to write Lenore could be afloat in a river because he wanted the river to be clean from dirty garbage.

Poe chose Stygian River to be his fantasy river because he had a reason. Poe's reason was related to the fact that the dirty river contained panthogen that killed people. In spite of the fact that the river was becoming the life source because it gave the water that people needed, this river also killed people because the water of this river contained germs. Poe detected the bad smell of this river and saw the dirty condition; thus, he also saw the promise of death given by the river. Poe imagined the river is killing people with its poisonous water. 
In Poe's eyes, the river is the symbol of death. He chose Stygian River to become the river in Lenore because in spite of fact that the river was described in the poem as clean, it contained the souls of death people. Thus, the Stygian River to Poe, is also giving him the same creepy feeling like the real dirty, full of garbage river did to Poe.

\section{C. “...No tear? -Weep now...”}

This phrase appeared as the opening of the conversation between the narrator and Guy De Vere. The one who opened this conversation by using this phrase was the narrator when he said, "And, Guy De Vere, hast thou no tear? -weep now or never more!” (Parker, 2005, Lenore, p. 193, stanza 1, line 3). From this line, it could be interpreted that the narrator did not only ask De Vere but the narrator also suggested him to cry at that moment.

When Guy De Vere did not accept his suggestion, it showed up the individualism and gloomy characteristic of the Dark Romanticism era. Guy De Vere was told to be in his sadness from losing his lover, thus, it is fine for him to show his sadness to others. The narrator, however, did not see the signal of his sadness. It made the narrator gave him the question.

As a reader, we may expect that De Vere was very sad and he was having a will to cry. In the poem, it was described that even though De Vere wanted to shed tears, he also had a will to look strong. De Vere most likely thought that if he weeps and seems week, he would be underestimated by the narrator. He wanted nobody to take pity on him. Thus, Guy De Vere desired not to be weak can represent his individualism despite the reality that he was in his sadness. This condition had a relation with Poe's life when he was alone after the death of his foster mother and Virginia. When Allan had married again after the death of his late wife, his new wife gave the signal that she did not like Poe. It made Poe decide to leave them. Poe thought that he had to look strong because he did not want to be pitied by them and so, he started to live alone. He did not look for any help from others because he wanted to find a new life for him on his own.

In reality, after the death of Virginia, Poe did the same thing. He did not look for any help or companion to help him overcome from his sadness. Sadly, the loneliness created by himself led Poe to run into alcohol. Nevertheless, Poe's courage to survive on his own suggested that Poe lived on to his individualism character. 
Lenore

\section{D. "Lenore"}

"Lenore" is a girl name that becomes the title of this poem. This name also appeared in stanza 1 line 4 and stanza 3 line 3 . The person who mentioned this name was the unknown narrator. The narrator brought in the name into the conversation when the narrator said "See! on yon drear and rigid bier low lies thy love, Lenore!” (Parker, 2005, Lenore, p. 193, stanza 1, line 4). The narrator mentioned this name again, twice, in this part of conversation. In this part, the narrator was described as arguing to Guy De Vere about Lenore's death, and was saying the following:

Peccavimus; but rave not thus! and let a Sabbath song

Go up to God so solemnly the dead may feel so wrong!

The sweet Lenore hath "gone before," with Hope, that flew beside

Leaving thee wild for the dear child that should have been thy brideFor her, the fair and debonair, that now so lowly lies,

The life upon her yellow hair but not within her eyes-

The life still there, upon her hair-the death upon her eyes.

(Parker, 2005, Lenore, pp. 193-194, stanza 3, line 3)

Lenore in this poem became the symbol of Guy De Vere's light. When Lenore disappeared from Guy De Vere's life, he was described as losing his light and guidance. Guy De Vere tried to accept the reality that his light has disappeared. He was almost successful to comfort his heartbreak but he still did not want to call her name. It made Lenore represented a dreary tone and an unhappy ending. This symbolization related to Poe's life, when after Virginia's death, Poe did not walk in the right path. He lost himself by running to alcohol. He thought that there was no guidance that led him to the right path and so he poured his sadness in alcohol consumption.

The poem, Lenore also suggested Poe's imagination of Virginia, who could have grown up to be an elegant lady who could support him. In reality, although Virginia was a graceful person, she was still a teenager when Poe decided to marry her. She was still a 13-year-old-girl who married with her cousin who was 14 years older than her.

Virginia was an elegant lady in Poe's imagination. Perhaps at Virginia's age at the time, Virginia still did not have an idea about how hard life was because she was still in the age of enjoying life. When Virginia became Mrs. Poe, she had to act older than her age. It made her need Poe to help and lead her. Though Poe was happy to do it, he also imagined that it was Virginia who would support him in his sorrows. Unfortunately, due to her sickness, she 
could not give her full support and could not help Poe because she was the one who was more in need of Poe. This is probably why Poe created poems with the imagination of an older Virginia, which was more elegant and stronger than the real Virginia, who was suffering from tuberculosis.

\section{E. "Death"}

The word "death" appeared twice in Lenore. The first time was when Guy De Vere replied to the narrator about the death of the innocent:

Wretches! ye loved her for her wealth and hated her for her pride, And when she fell in feeble health, ye blessed her-that she died! How shall the ritual, then, be read?-the requiem how be sung By you-by yours, the evil eye,-by yours, the slanderous tongue That did to death the innocent that died, and died so young? (Parker, 2005, Lenore, p. 193, stanza 2, line 5)

The second time "death" appeared was in the narrator's answer to De Vere in the next stanza when he stated "The life still there, upon her hair-the death upon her eyes." (Parker, 2005, Lenore, p. 193-194, stanza 3, line 7). In the second stanza of Lenore, Guy De Vere stated that death happened to the pure and young Lenore, meanwhile the narrator said that the death existed only in her eyes.

The death that De Vere said was the death that naturally happened to all human beings. In this case, he was referring to the end of Lenore's life, which was natural. Yet. this death, however, was different from the death that the narrator meant in the next stanza. Because the narrator still saw Lenore as still physically alive, the narrator took the chance to look at her eyes. It is here, that he knows that her spirit is gone. The narrator says this fact twice in stanza three when the narrator implies it in the previous phrase, "The life [is] upon her yellow hair but not within her eyes".

The narrator says the word death for two times, because he saw the death in Lenore's eyes for two times. The first time happened when Lenore knew that she was diagnosed with tuberculosis and the second time referred to when she felt that she was going to die soon. Lenore's spirit of life was decreasing by time to time during her sickness to finally make her spirit die when she knew nothing could help her anymore. It is possible that, this was the death that Poe saw in Virginia's eyes. 
Lenore

As with any husband, Poe must have supported Virginia with the hope that everything was going be fine and that she was going to be cured. Sadly, Virginia knew the reality that she was going to leave Poe because she could feel that tuberculosis was killing her slowly. She also knew that there was no medical treatment that could cure her. Even if there was a medicine or medical treatment, the condition of the environment at the time, could bring other diseases that could kill her. This was the reason why although she smiled and acted happily, there was no hope and no spirit of life in her eyes. This was the death that Poe met in Virginia's eyes when she was still alive. The word "death" in the poem represented the gloomy feeling, dark, and dreary tone of the Romanticism era.

\section{F. "Peccavimus"}

"Peccavimus" appeared in stanza 3 line 1 when the unknown narrator said to De Vere:

Peccavimus; but rave not thus! and let a Sabbath song Go up to God so solemnly the dead may feel no wrong! The sweet Lenore hath "gone before," with Hope, that flew beside, Leaving thee wild for the dear child that should have been thy brideFor her, the fair and debonaire, that now so lowly lies, The life upon her yellow hair but not within her eyes The life still there, upon her hair -the death upon her eyes. (Parker, 2005, Lenore, p. 194, stanza 3, line 1)

Through the above stanza, the narrator has chosen to say "Peccavimus" to symbolize the responsibility and punishment that De Vere had to have. In the narrator's opinion, he thought Lenore's death was the man's fault and he wanted the man to take the responsibility. The reason why the narrator thought that Lenore's death was the man's fault was because the man knew that Lenore was going to die but he did nothing to prevent it. The feeling of sadness and unhappiness due to Lenore's death were the punishment that De Vere had to have for his entire life. This kind of responsibility was also felt by Poe. When Poe realized that his wife was positive in having tuberculosis, he knew that she would die.

Knowing about Virginia's eventual death, Poe described in stanza 3 of his believe that there ought to be ways of curing the dying Virginia because he thought that it was his responsibility as a husband to save his lovely wife. Sad to say, he could not do anything to make it happen. It happened because at the time it was very hard to maintain the healthy condition due to the 
situation of dirty environment and Poe's economy condition. Thus, Poe could only stay by Virginia's side and watch her slowly die. Perhaps at the time Poe felt that he was evil because he did not prevent his wife's death. It made Poe felt in a despair until he wanted to take the punishment to be unhappy for his life. This was the reason why the word "Peccavimus" bear the dark and gloomy feeling because it pushed someone to feel despair and sad.

\section{G. "Hope"}

In Lenore, the word "Hope" appeared in the third stanza when the narrator replied to Guy De Vere with a phrase "The sweet Lenore hath "gone before," with Hope, that flew beside" (Parker, 2005, Lenore, p. 194, stanza 3, line 3). Reading this phrase, the word "Hope" with capital "H" may make readers think more about its real meaning. We may perceive this word to refer to Guy De Vere. The reference is not to his body but to his soul and love that accompanied Lenore to heaven. The narrator saw this fact, which was why he gave the capital $\mathrm{H}$ when he said the word "hope" to respect De Vere. Interpreting the poem about De Vere, it could be said that he accepted the reality that Lenore has gone, and he should live-on to the next life, but in reality, he still felt heartbroken. He was in sadness and despair, but he believed that Lenore was happy and waiting for him in heaven.

"Hope" in this phrase could also symbolize Lenore and De Vere's wish to be happy together in a marriage. It can be proven in stanza 3 line 4 when the narrator continued the previous line with the phrase "Leaving thee wild for the dear child that should have been thy bride -". The words "the dear child" in this line referred to the hope of marriage that De Vere and Lenore tried to make to happen. Sadly, their hope could not come true because of the death of Lenore. It made their dream of having a child became only a dream for Lenore to bring to heaven.

"Hope" could also represent Poe's wish for Poe and Virginia to have a better life. In reality, Poe tried to make a better life for them even if it was hard to do with his job as a writer at the time that did not produce enough financially for them. Poe did not give up easily on their dreams, so he worked hard to make it happen. Unfortunately, their wish of a better life with a child could not be fulfilled due to the condition of the environment and the death of Virginia. This word contained Poe's feeling of unhappy and lifeless feelings after the depart of Virginia. In other words, this word represented dreary tones and an unhappy ending, too. 


\section{H. "Grief and Groan"}

The phrase was located in Guy De Vere's part when he wanted to talk to the unknown narrator for the last time.

Avaunt! to-night my heart is light. No dirge will I upraise, But waft the angel on her flight with a Paean of old days!

Let no bell toll!-lest her sweet soul, amid its hallowed mirth, Should catch the note, as it doth float - up from the damnéd Earth.

To friends above, from fiends below, the indignant ghost is rivenFrom Hell unto a high estate far up within the HeavenFrom grief and groan, to a golden throne, beside the King of Heaven. (Parker, 2005, Lenore, p. 194, stanza 4, line 7)

From the last stanza, it was interpreted that De Vere believed he had to pass his lowest point of life to reach heaven. De Vere thought that the lowest point of life was the time when he was in very deep despair or sadness of his life because of his late Lenore. When seeing the phrase "From grief and groan", it could mean that the despair or sadness that De Vere wanted to say was not the feeling that could easily erased and forgotten. It is the strong feeling of when he could have a mind to give up his life and committed suicide. This strong feeling of sadness and pain could have made De Vere cried out because he could not bear this heavy feeling. It was also proven by De Vere when he said "From Hell unto a high estate far up within the Heaven - "shown in stanza 4 line 6. This line showed that the feeling of grief, that made him in the lowest stage of life, tortured him like hell. It can be interpreted that the feeling of sadness and pain that De Vere had to experience referred to the life of Poe.

Pain and sadness in this phrase can be said to refer to three things in Poe's life: Poe's hard life, tuberculosis, and the death of his beloved women. Reference to Poe's hard life coincided with Poe's biography, where he was found struggling with his life after leaving the Allan's family. It must have been hard for Poe, when he had to decide to leave his comfort zone. He had to lose everything to try and start a new life.

He was still struggling to have a proper life even after he married Virginia. The cause of his hard life came from the environment and situation at the time which did not support his dreams at all. Even after Poe worked to earn his well-deserved money, he still did not escape from poverty. It was because the salary or wages that Poe had earned was little and everything was 
expensive, so Poe did not have enough money to cover all of his daily needs and it made him suffer with poverty.

This phrase also refers to tuberculosis, because the pain caused by tuberculosis did not only come from the pain that Virginia felt but it also came from the sadness that Poe had when he watched Virginia suffered and died because of this disease. Poe could not do anything to prevent the death because the condition at the time did not support him to find proper help. Thus, he could never forget the pain and sadness that came from the death of his beloved one. As shown in the poem, Poe really put his gloomy feeling in this phrase.

\section{CONCLUSION}

As learnt by looking into the biography and society of Poe's life, the poem Lenore is found to show up Poe's experiences about losing his beloved mother and wife, who died due to tuberculosis. The death of his loved ones made him feel a deep sadness and grief that cannot be erased easily. The bad condition of environment at the time, thus, influenced Poe to produce poems that show the Dark Romanticism era, which was filled up with a gloomy and dark life. Thus, in addition to the phrases "no tear... weep now", "grief and groan", "Stygian River", "golden brown", there are also the words, "Hope", "Peccavimus", "Lenore" and "death" in the poem".

\section{REFERENCES}

Case, K. A.; \& Semtner, C. P. (2009). Edgar Allan Poe in Richmond.

Didier, E. L. (1879). Life of Edgar A. Poe. Retrieved August 10, 2017 from https://www.eapoe.org/papers/misc1851/eld18791.htm

Dinçer, F. (2010). The Light and Dark Romantic Features in Irving, Hawthorne and Poe. Journal of International Social Research, 3(10), pp. $218-224$.

Frith, J., \& Villemin, A. (2014). History of Tuberculosis . Part 1 - Phthisis , consumption and the White Plague, 22(2), pp. 29-35.

Griffin, J. (2014). 1,107 Baby Names That Stand the Test of Time - Jennifer Griffin, p. 117. 
Khoe, Y.H., \& Dukut, E.M., American Dark Romanticism Characteristics in

Lenore

Habich, R. D.; \& Nowatzki, R. C. (2010). Romanticism and Transcendentalism. New York: Facts On File, Inc.

Hammond, J. R. (1981). An Edgar Allan Poe Companion (First edit). London and Basingstoke: The Macmillan Press Ltd.

Loughran, E. (2008). Critical Companion to Edgar Allan Poe: A Literary Reference to His Life and Work. School Library Journal (Vol. 54).

Matthews, A. (2014). American Transcendentalism and Dark Romanticism. https://www.academia.edu/8808289/Transcendentalism_and_Dark_R omanticism_in_America

McGraw-Hill Education. (2015). American Literature and History: American Romanticism (1800-1860).

Parker, M. P. (ed). (2005). Collected Works of Poe, Volume V. (V, Vol. V), Lenore, pp. 193-194.

Hennink, M., Hutter, I., \& Bailey, A. (2011). Qualitative Research Methods, pp. 8-9.

James, S. (2012). World Literature: Cultural Influences of Early to Contemporary Voicest, p. 315.

Stobaugh James. (n.d.). World Literature Student - James Stobaugh - Google Buku. Retrieved February 20, 2018, from https://books.google.co.id/books?id=d7Y_2dJQ7U4C\&pg=PA315\&lpg $=\mathrm{PA} 315 \& \mathrm{dq}=$ Stobaugh + romanticis + characteristics + the + imagination ${ }^{+} \mathrm{w}$ as+elevated + to $^{+} \mathrm{a}^{+}$position + as + the + supreme + faculty + of + the + mind $\&$ sour ce=bl\&ots=6NHbq6QMsd\&sig=osWFWVJfJHEX_kLgxjGJNrCcA\&hl=id\&sa=X\&v

Taylor, D. E. (2009). American Environmentalism: The Role of Race, Class, and Gender in Shaping Activism 1820-1995. Environmental Sociologyfrom Analysis to Action, pp. 307-326.

Wellek, R. (1962). Introduction: A History of Dostoevsky Criticism. Dostoevsky A Collection of Critical Essays, pp. 1-15.

Wilson, S. (2015). Simply the Best Baby Name Book, pp.104-105. 
300 Celt: A Journal of Culture, English Language Teaching \& Literature, Volume 20, Number 2, December 2020, pp. 282 - 300

\section{APPENDIX:}

\section{LENORE}

Ah broken is the golden bowl! the spirit flown forever! Let the bell toll!-a saintly soul floats on the Stygian river; And, Guy De Vere, hast thou no tear?--weep now or never more! See! on yon drear and rigid bier low lies thy love, Lenore! Come! let the burial rite be read-the funeral song be sung!An anthem for the queenliest dead that ever died so youngA dirge for her the doubly dead in that she died so young.

"Wretches! ye loved her for her wealth and hated her for her pride, "And when she fell in feeble health, ye blessed her-that she died! "How shall the ritual, then, be read?-the requiem how be sung "By you-by yours, the evil eye,-by yours, the slanderous tongue "That did to death the innocent that died, and died so young?"

Peccavimus; but rave not thus! and let a Sabbath song Go up to God so solemnly the dead may feel so wrong! The sweet Lenore hath "gone before," with Hope, that flew beside Leaving thee wild for the dear child that should have been thy brideFor her, the fair and debonair, that now so lowly lies, The life upon her yellow hair but not within her eyes-

The life still there, upon her hair-the death upon her eyes.

"Avaunt! to-night my heart is light. No dirge will I upraise, "But waft the angel on her flight with a Paean of old days! "Let no bell toll!-lest her sweet soul, amid its hallowed mirth, "Should catch the note, as it doth float - up from the damnéd Earth.

"To friends above, from fiends below, the indignant ghost is riven"From Hell unto a high estate far up within the Heaven"From grief and groan, to a golden throne, beside the King of Heaven."

Taken From: Collected Works of Poe, Volume V, pp. 193-194 